\title{
Untitled: Never Forget You Look Great II Map to Misogyny
}

\author{
Patricia Seaman
}

\section{Sans titre: N'oublie jamais que tu as l'air sensationnel II Carte de la misogynie}

Grâce à une juxtaposition de textes, ce collage génère une série d'espaces à découvrir entre les systèmes sémiotiques de la culture urbaine. Panneaux-indicateurs, talons, pamphlets religieux, diagrammes anatomiques, publicités de concerts, horoscopes, bandes dessinées, images religieuses; par qui ces systèmes sont-ils lisibles? Quelle est leur grammaire? Quelle est le syntaxe de la ville? Patricia Seaman interprète le deuil public qui a suivi les fusillades de jeunes Noirs à Toronto au début des années 1990 comme une période de résistance collective aux idéologies dominantes de protection policière et de lutte contre le crime. Ne trouvant aucun réconfort dans la résolution du crime et l'établissement du blàme, la narratrice vise plutôt à exposer la complicitéentre les médias et les forces policières, gardiennes du racisme. Elle attire aussi l'attention sur la multiplicité de cartes urbaines qui conspirent à promonvoir les intérêts dominants. Comment se fait-il, par exemple, que seuls ceux qui ont les moyens de se payer une voiture peuvent circuler en sécurité dans les rues de la ville? Dans quelle mesure la prospérité de la ville dépend-elle du désaffranchissement des femmes, des minorités visibles, des sans emploi et des bas-salariés? 


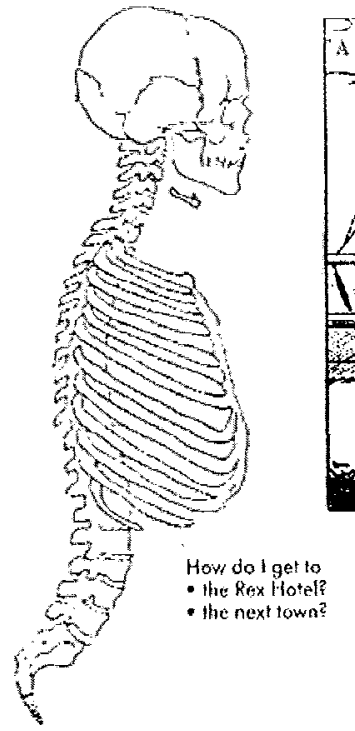

When mourning goes public someone is responsible. A procession of peopleareweeping in the cemetary. Too late the authorities try to vindicatedeath. Act normal and be inconspicuous. This is friendly advice. See, no weapons. My hands are shaking and I hide them behind my back. I get an idea right away about what I'm going to be. I compose letters of protest in my head. Allkinds of accusations! I'll have to go on the road. Worse, underground. This isn't news to you. You must have known all along. Itwasinall the papers. You can't be sure anymore but never forget your suspicions.
Nothing is the same after the first shooting. I want mediocrity. I scream out for it in my sleep. I have some sort of an idea about innocence, notmy own.

The papers are syndicated. They are an association designed to carry out a business or commercial undertaking. My confidence in the future is strong. The idea of infinite progress is embedded in my thinking and spreads asinsolubly as mercury. I'm an arrogant $\mathrm{dog}$, unafraid of being consigned to poverty. Anyway it doesn't happen here. And me too it's

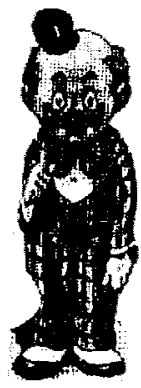
always easy for me too insidiously in my ignorant compliance.

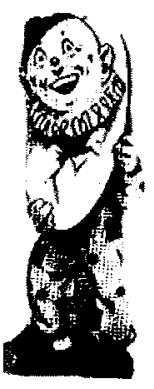




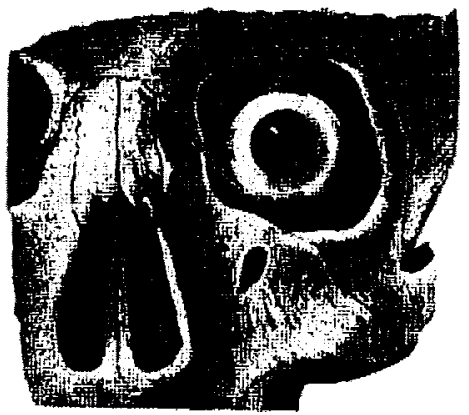

\section{Get in touch with yourself}

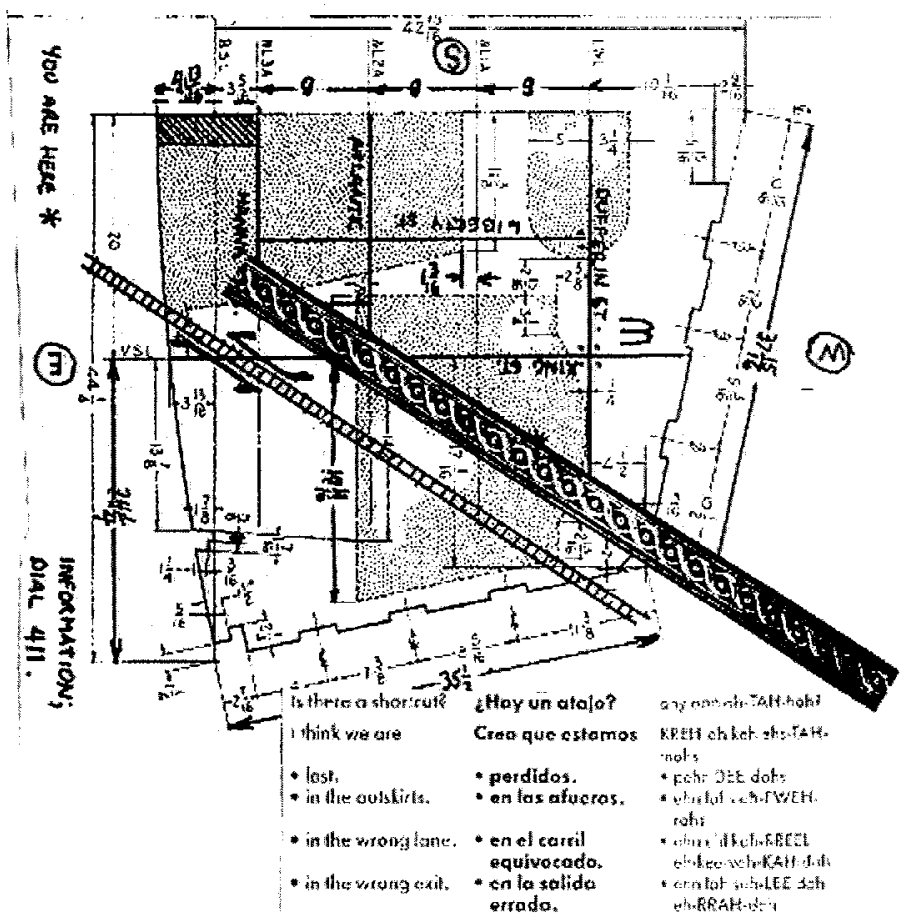


How can I get some satisfaction out of this way of living. I sit in front of the TV and accumulate worry. I worry about everybody on the news. Not to mention, the girl upstairs is trying to steal my boyfriend. She shows up in moments of distraction and in my absence. She is the simplest thing in my life. She gives me something to focus my anxiety on. However, she gets bored quickly. And so do I. I have other things to think about. As usual the dog is at the door. The machinery continues to function. I read the classifieds every day. The city changes overnight. I get lost on my way to the store. I wonder how am I going to find a job.

Later I realize. I shout obscene words. I curse them. I know who is to blame. I devise an elaborate hex.I describehis body perfectly, the large hands, the hairs, the expressionin the eyes, height and weight. I plan the perfect accident, something likely, something easy. But then I'm only imitating his gestures. Talking like him, using his language, his accent. Ican't believe it. It's going totakeyears tocleanup thismess. We should start right away. I think that I'm no longer capable of cruelty. Which requires power. And I haven't got any. Not a dime's worth.
It's the same old accident. Rejectionseemslessandlessarbitrary.I go back to worrying about everyone on TV. Experience doesn't make any difference. It lacks exactitude. The frontiers of knowledge are receding. I begin to rely on fantasy. I am becoming dangerous to myself and others. I fall into their hands continuously. I trust anybody. I want to believe. Stupidly, as lazy as a dog.

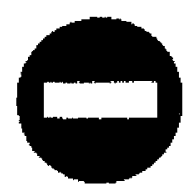

Thestreets are cordoned off. It's a waste of strength looking for a taxi. Officials take complex routes through downtown in huge black limosines. Their whereabouts is shrouded in secrecy. The police round-up the homeless like so many lost sheep and take away their liberty which is thelast thing theyhave. There is a massive show of forcein front of the embassy. I'm terrified by the sight of so many uniforms. I'm afraid of guns. I start getting an idea. I feel as though I've sunk beneath the surface of a small sea. A sea of petrol. My tiny fist shaking. My feathers drenched in the suffocating muck. 


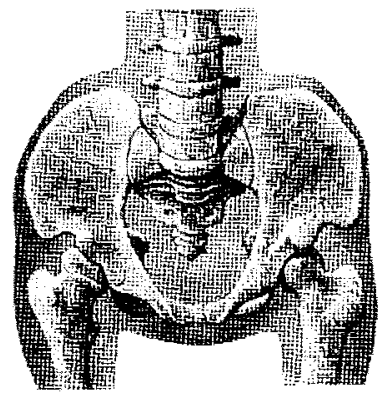

There is continuous official intervention. Checks arrive at the house every two weeks and young men appear out of nowhere to collect them turning themover and overin theirhands and putting them in their back pockets. They go out into the streets and the streets mislead them. As trusting as boyscouts. They are not lost but he is preoccupied with a never ending list of delicious names like peyote. And I say $\mathrm{G}$, who are these guys. And he says, they're friends of mine. And they provide a valuable service to the system because everyone knows it can't support full employment. And as for you, he says, the economy would collapse if we paid women a living wage.

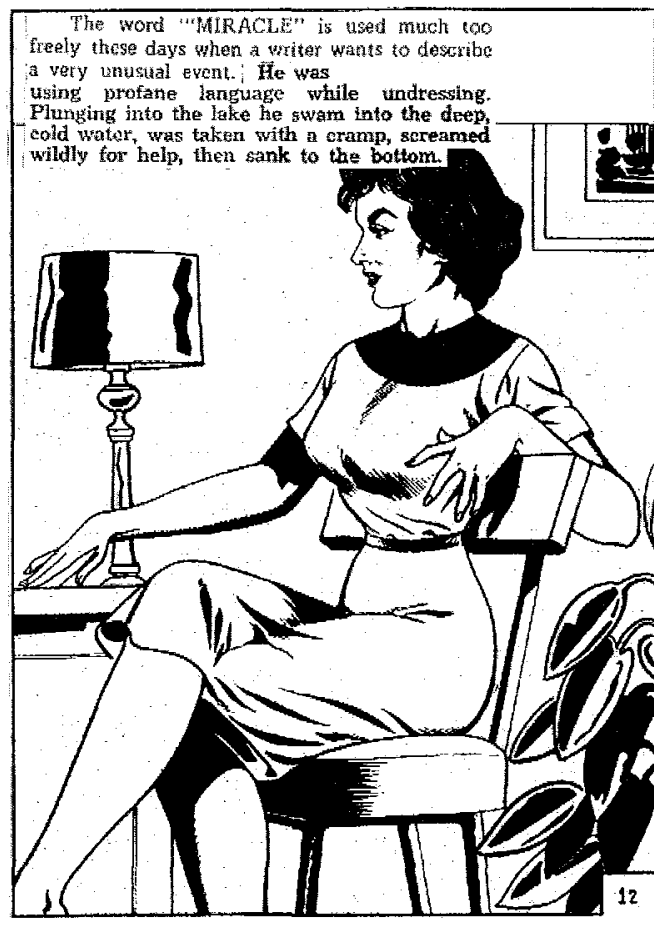

\begin{tabular}{|c|c|c|}
\hline l'a hatsected. & Fengo nâuseas. & 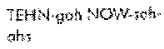 \\
\hline $1 \operatorname{con}^{\prime} i \operatorname{sect}$ & No puedo domuir. & $\begin{array}{l}\text { Mat PWEHdoh doh: } \\
\text { MEEP }\end{array}$ \\
\hline I thets og. & Vomito. & rah-mis IEH \\
\hline Stowe diarthea. & forge ditatea & $\begin{array}{l}\text { TEStri-zoh dyokn } \\
\text { QREt-oth }\end{array}$ \\
\hline t'meonstipa:ced. & $\begin{array}{l}\text { Entoy } \\
\text { Bstreñda(-a) }\end{array}$ & 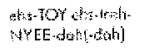 \\
\hline
\end{tabular}




\section{ON THE ROAD}

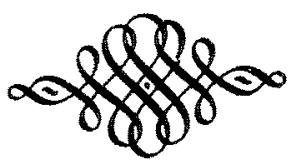

Isee the police.Iturnaway, I want to throw up, my stomach! They make some kids get in the back of their cruiser. I want to yell, Hey, don't shoot those kids, I'm watching you! What's unbearable, outside of the unbearable fact of the shootings, is the

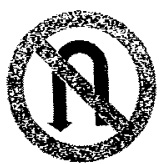
NO U-TURA complicity of the newspapers with the police.

\section{American Manual Alphabet for the Deaf.}

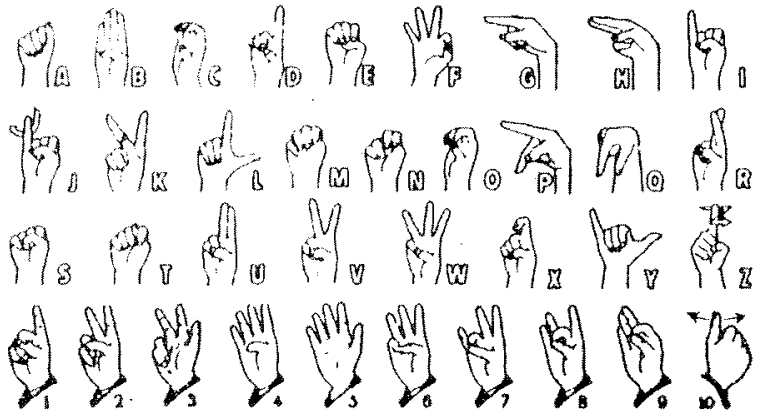

Oh, unsaved reader, stop and think a moment of the awful, sudden end of one who chose the vain, fleeting pleasures of this world instead of accepting Jesus Christ as her Savior. Are you doing likewise? Are her words, 'I'm in for a good time," the sentiment of your heart too? Is this the bent of your life-"pleasures of sin for a season?" (Heb. 11:25). Do you belong to the class who are "lovers of pleasure rather than lovers of God?" (2 Tim. 3:4, N. Tr.). If so, be warned by this incident.

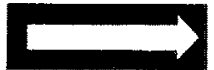

ONE WAY

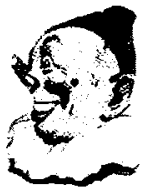

Travell

Tourism DIPLOMA 
I'm taking an unguided tour into

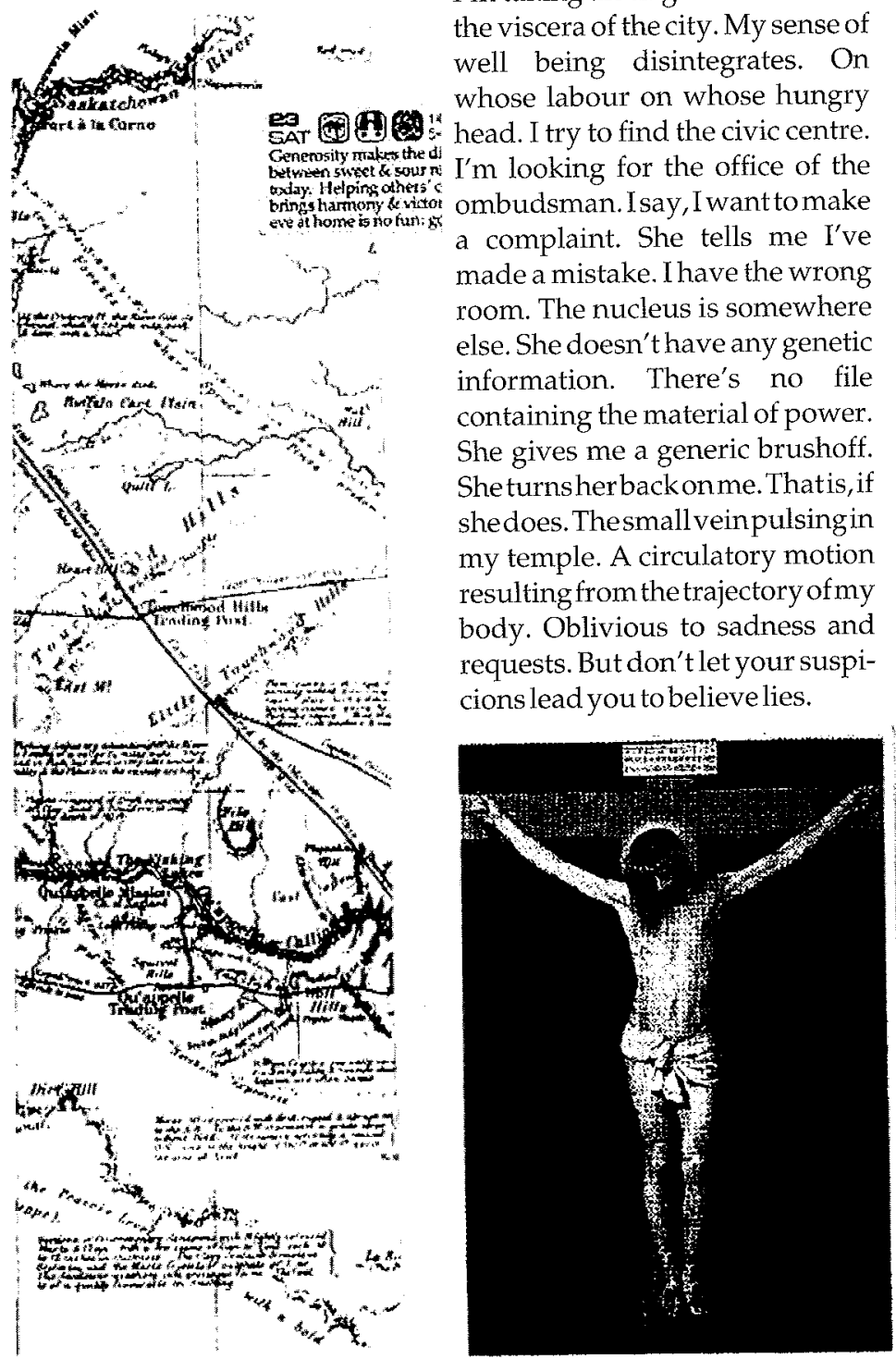




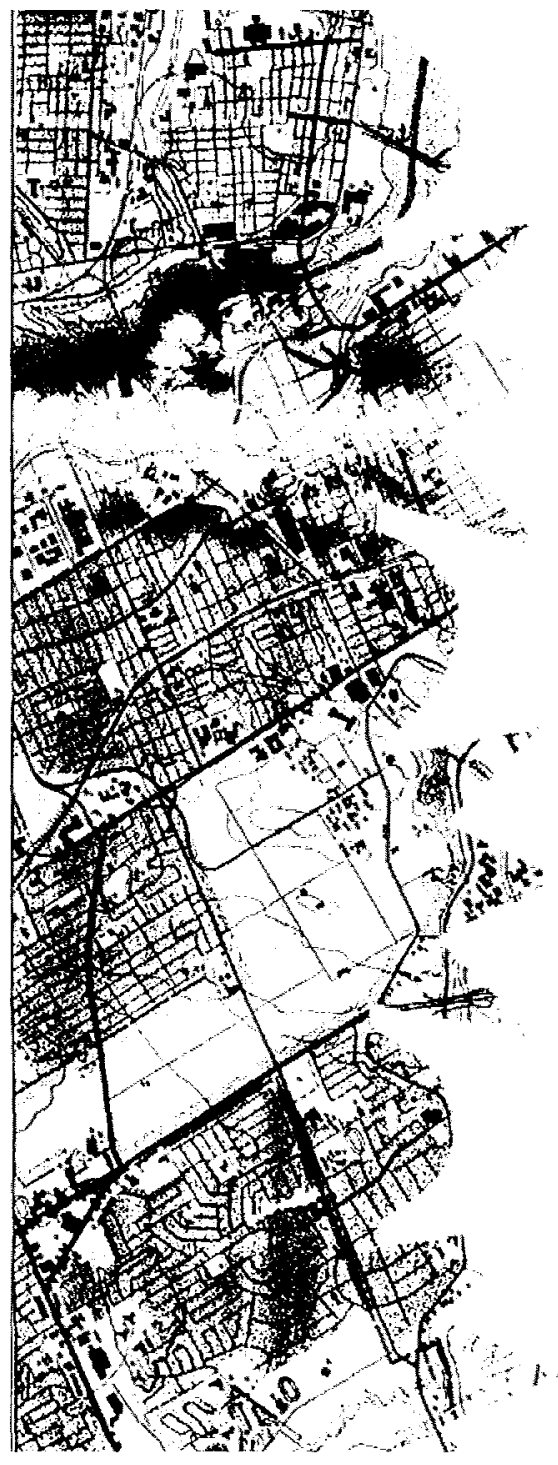

\section{WAITING FOR THE RIGHT}

\author{
* Money \\ * Relationshar
}

Spaced out. Or, way out in space together. G never closes the door to his room and I can hear him in there singing happily to himself. Gathering our fools share of angst and making spaghetti sauce. He is horrible all day long and follows me to the bathroom that me and my boyfriend and $G$ and his girlfriend and $R$ and his dirty laundry share in perfect harmony. Atleast Ghas this thing aboutcleanlines and Inever have to do it not once in all the months I've lived here. Anyway we are very busy inventing alternative landscapes. $G$ goes fishing at night at Pickering. He says it's warm and that the fish are easy to catch because they glow in the dark. I say, is that true. The thing is he eats it.

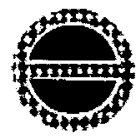




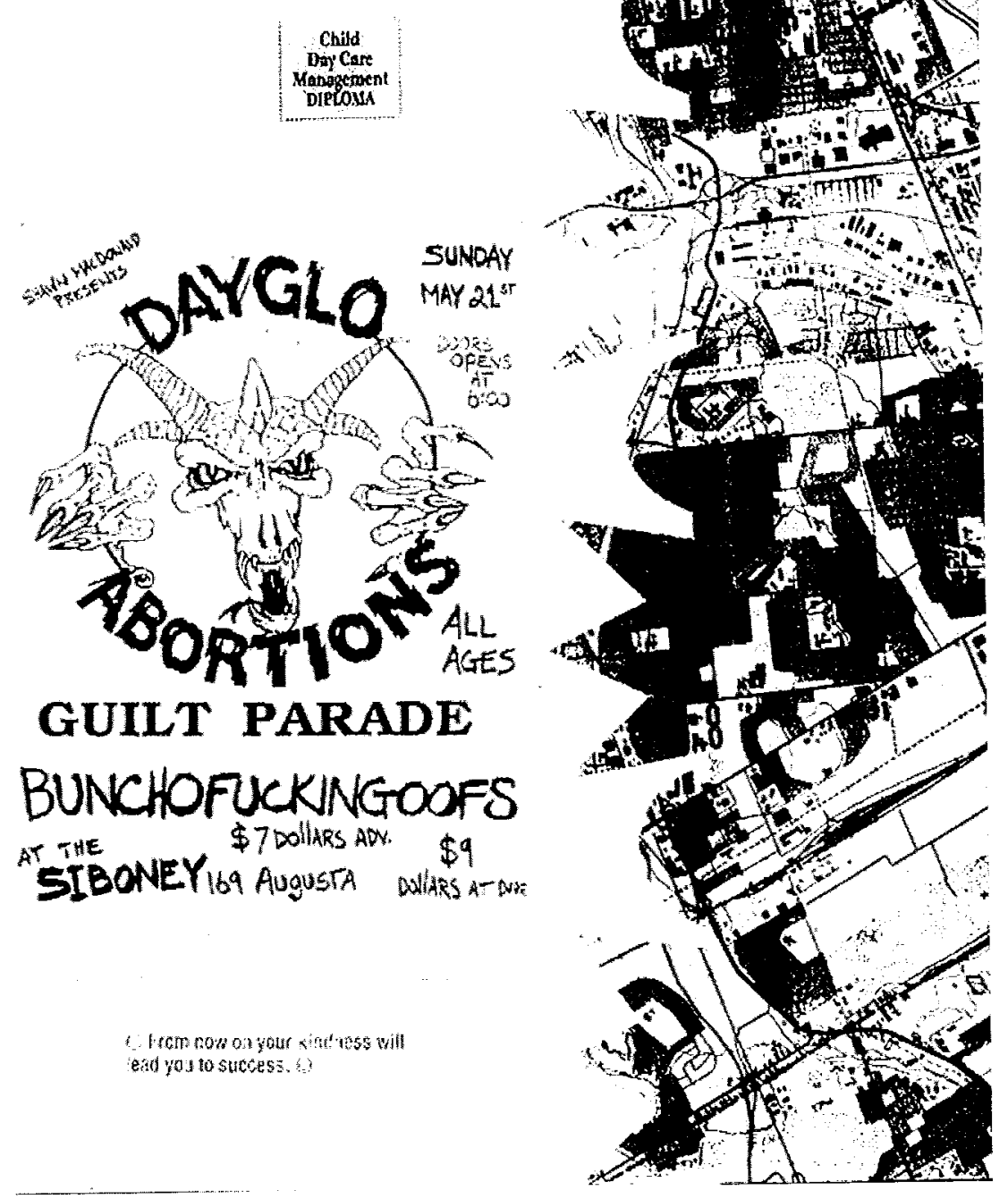


The object of his desire supports him. His black uniform. His violent willingness on a July evening. Later he can say it was an accident. We are all made of marrow and other bonestuff, like calcium, like minerals. Which reminds me I forgot to make the bank deposit. The check in my wallet is good for nothing. Blood orchampagneisflowing through my body and I can feel its tiny bubbles bursting in a dozen loci at once. Depositing the desire to go on. We can never get away from it. What are the police anyway. The police are the guardians of racism and the people demand that the guardians of racism stop being racist. Once this is finally accomplished, being disgustingly overdue, what will beleft of the police. Hopefully, very little.

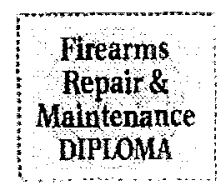

The caption in the paper reads, This Dramatic Photograph was Taken Seconds After the Shooting. I Mean! What the Hell! This is not the cinema. This is not the theatre. This is not fiction. This is ourblood.
When I imagine that it has finally got to be all over, that they wouldn't dare do it again, that even the press will be forced to stop their support of this outrage, then they shoot someone else. I feel like crying. So what. It doesn't do anybody any good. I walk close to kids on the street keeping my eyes wide open for cruisers. As if my skinny woman's body was enough to deflect bullets which it isn't. Damn.I Thear it on the radio again I can't believe it. The announcer says, There are still women who are naive enough to think, It won't happen to me. There are still women who walk around alone, there are still women who go out after dark. I yell at him, Damn you! Shut up! If every woman in Scarborough went out after dark every single night it wouldn't be the women, it would be the rapist who would be afraid. What do you think all this take back the night for the last twenty years has been about. Women are not nearly as naive as the media... The problem is the plan of the neighbourhood. The layout of the streets is a deadly maze. They're designed for cars. They're designed for drivers. I can't afford a car, can you afford a car, who can afford a car.

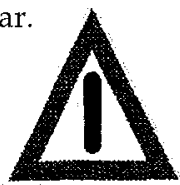

DANGER AHEAD 


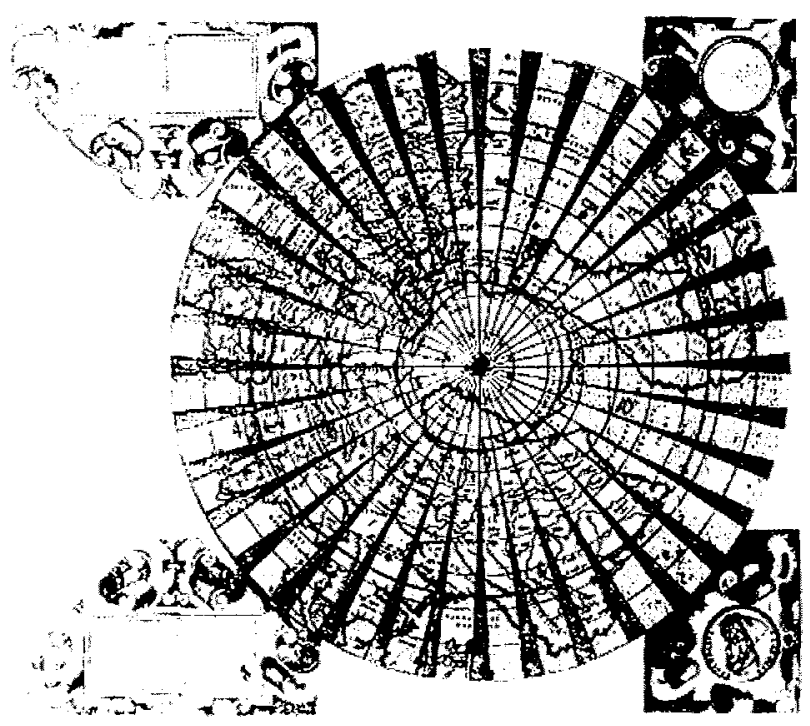

Our lives are not normally nervous by some luck. The uniforms are generally hung in the closet waiting for an occassion. We don't usually see it and most of us don't know about it. We should ask ourselves which of usdon't know aboutitand why we don't. Some of us got in the way of finding out about a few things at the anarchist's picnic. Things began to be clear. Information was disseminated in a hundred unsuspected ways. We knew things we didn't know we knew. We had the map out on the floorbutwe could havefound our way anywhere without it after that.
I praise the imagination of the women which is what saves me. The Super Nevada Club is the embouchure toenergy, intensity, desire, pleasure and awareness. We have a little utopia in the middle of the warehouse district, so there. Where we talk about the wine spodiodi of our lives. Wrapped up in a cozy rummy blanket of recognition, violently in love with each other or something. We agree to turn off the news. We bring gifts of food and something to drink. And all kinds of things that none of us suspected. We listen to music. But our haven finally breaks down because how can we not 
talk about the Montreal shootings. Like everyone we are sick at heart. And weknow whoyouare, you who are against us.

And then we even talk about Doris. Will public opinion send her back to Harry. And who is responsible for this gimmick and what is it all about anyway and who cares. It's insidious! I yell. Oh shut up why don't you, they say. You see misogyny in everything. Giveit a rest. And, Gobuy a round. Get me a Spanish coffee, willyou.
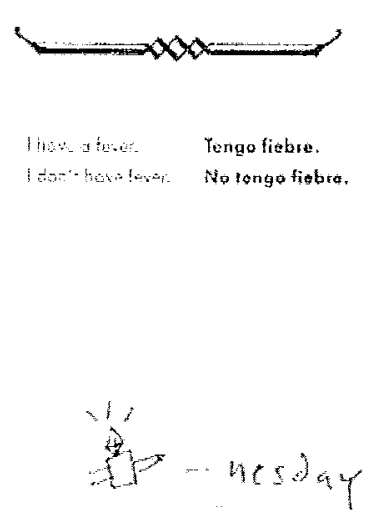

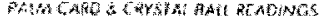

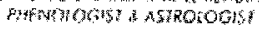

QUESTIONS :

PROBLEMS ?

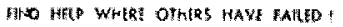

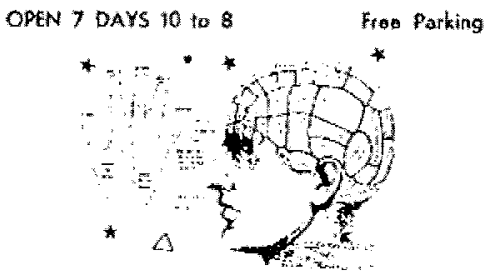

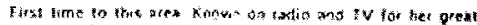

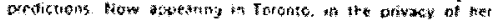

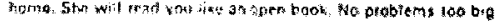

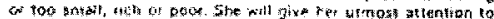

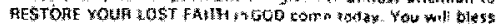

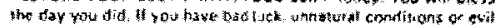

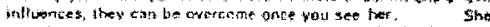

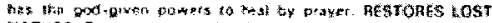

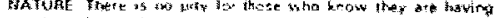

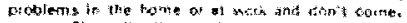

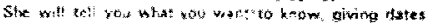

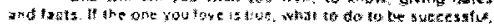

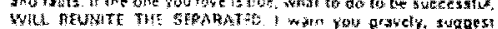

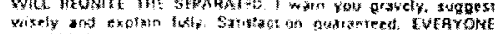

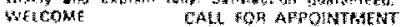

MMEDINHE SOLWHONS

TO YOWR problems

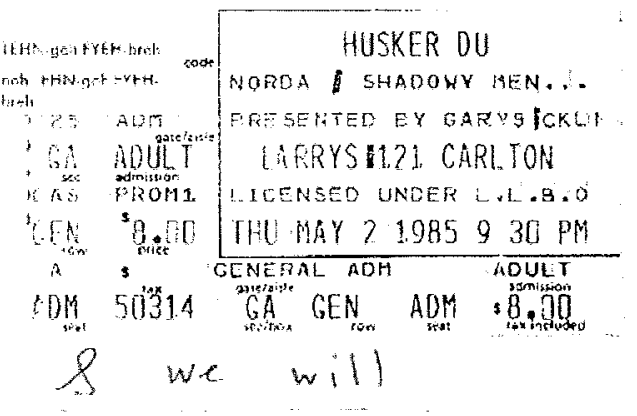




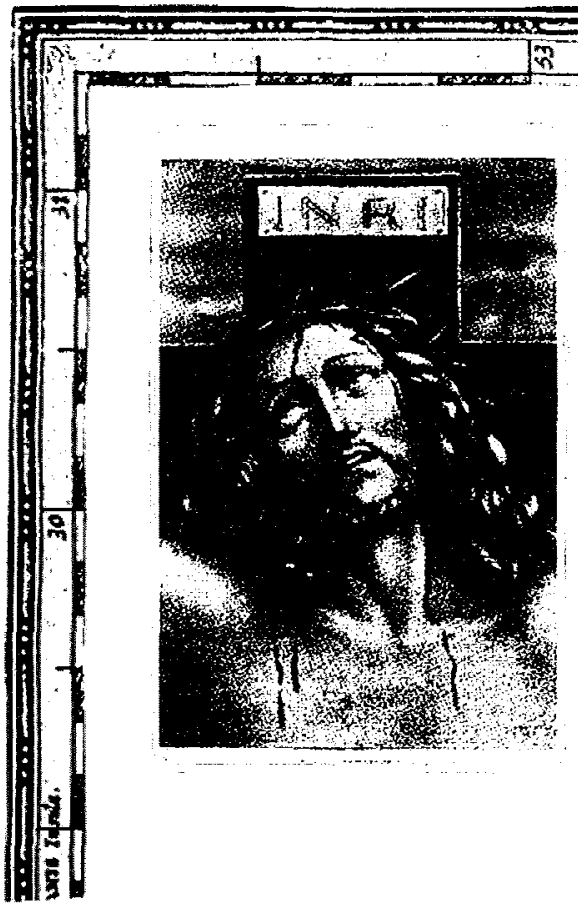

This shooting is a disaster for the police and it's about time. There has been a call for an inquiry. The web of infamy will be displaced. The provincial agencies are getting involved. They are promising to look into the force. The papers are giving their usual account. They talk about the shootings giving the barest facts and then the article goes on to talk about a sex scandal on the force. That's what's embarrassing them, sex embarrasses them. The newspapers are creating a spectacular purge. But wait a minute. These are not inevitable wounds. Refuse to be lied to. Alliances must be formed quickly. We should be banding together at all

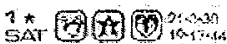
Juty be

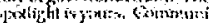

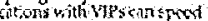
wo upriard. Infuse tow tif?

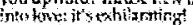
times because these things happen in a split second.

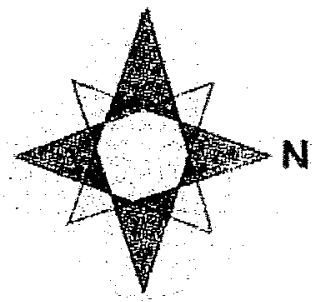

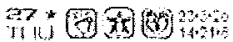

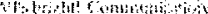

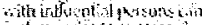

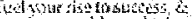

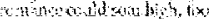
hoturion 


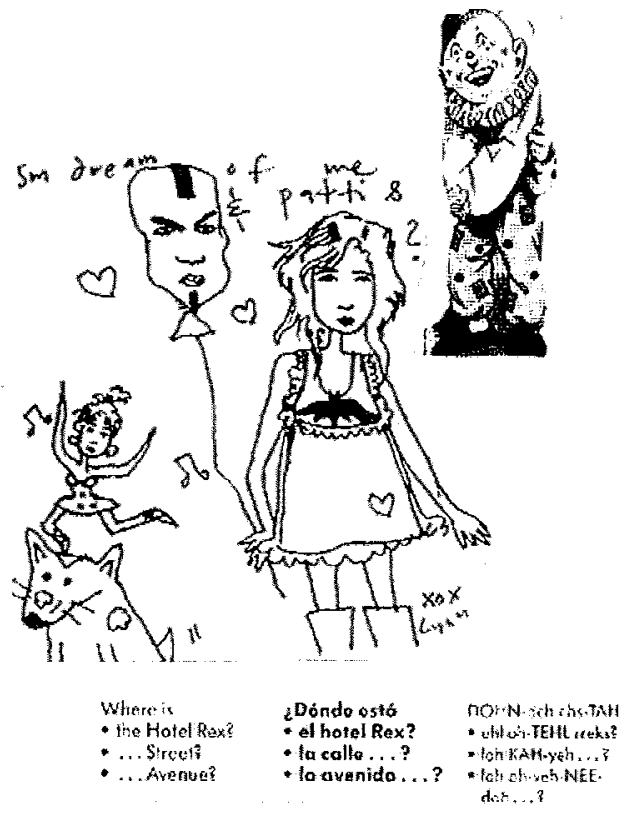

In this house scandal is rampant. He blames the tenants, he says he knows what we are up to. In turn weblamehim, we threaten to call in every available authority. We spend our days on the tenant's hotline. Finally we calm down. His red face and inarticulate denial when I confront him. He says that legally he'snotrequired toturn on the heatforanother two weeks. The few days of peace we have regained is shattered. My boyfriend and I sit on the mattress on the floor of the room that we live in and I yell at him, Getajob! Which isn't the point.

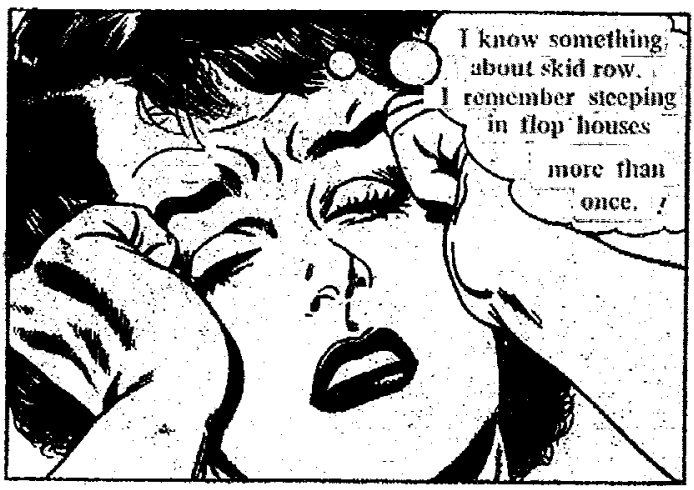


This vast plot is sinking into the veins of the systemlikeabadsci-fi novel. Except that in this book there is no escape. No amount of cunning can demolish these obstacles. They have to collapse in time of their own design problems. The hero sinks into a vague intermittent paranoia where not only does henotget the girlbuthe has to live in a bed-sitter. For the rest of his life. The face of fiction. is changing. It's been taken over by the syndicates. It can't keep up with these daily events. Italready knows too much. We are becoming attentive to small details. Ido something nice for him. He does something nice for me. We never mention fundamental thinking, if it's deteriorating to an absolute idea that failsmeaning. I'mon the look-out for quotidian acts. As if they exist without mediation. As if Ican identify pure sin, or necessity, or pleasure. He does somethingniceforme. Wehope that by this we can change the custom of death.

\section{"I Have Plenty of Time"}

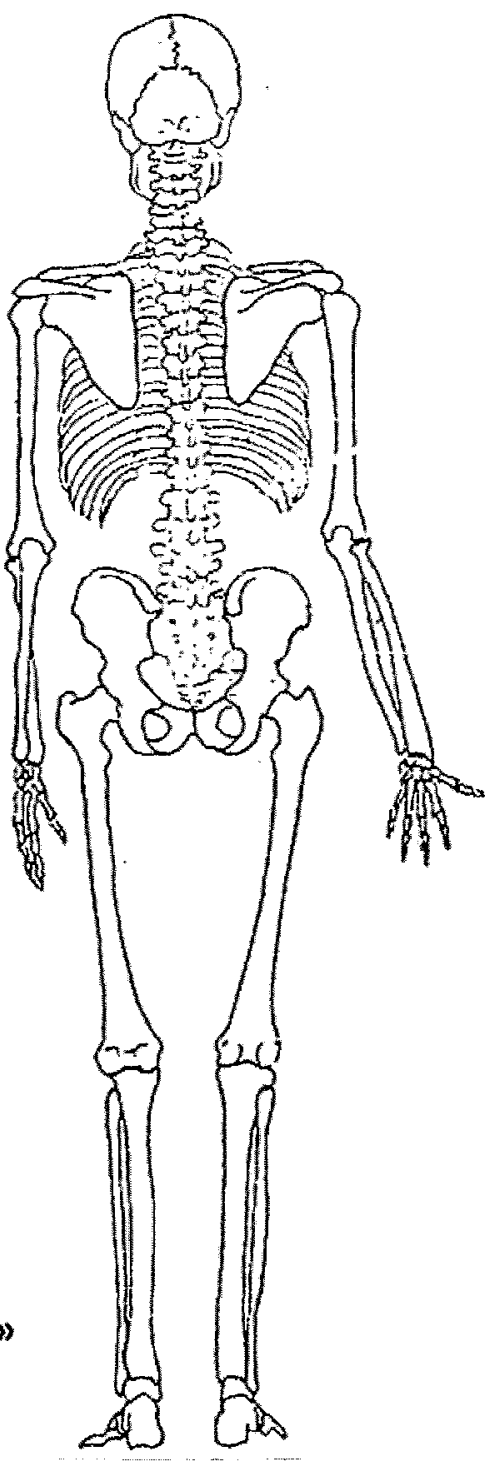


* Inspiation

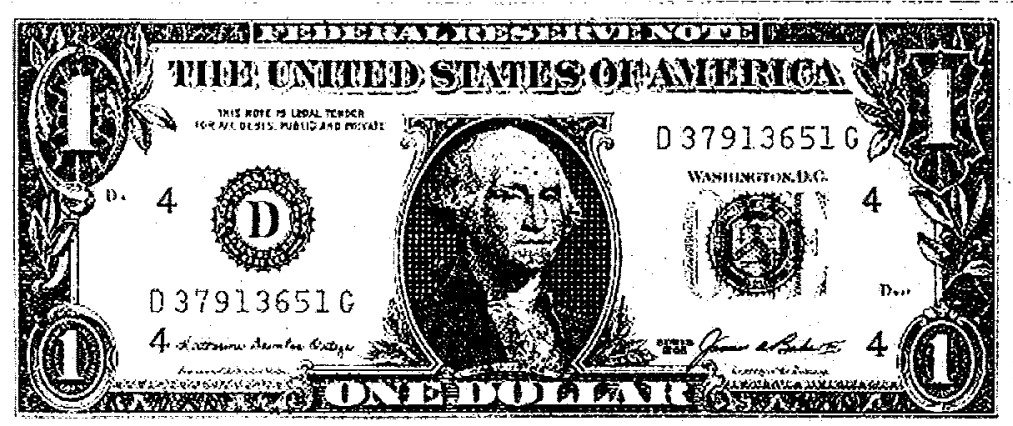

Night is passing. We women are alone with our thoughts.

The city takes care of its own needs. Thestreetsmapa perfectly defined territory begging for government. Campaign posters litter the neighbourhood. The placeisswarming withenumerators. Stand up and be counted.
A language of truth is falling through the cracks. What happens to the hero if she's a heroine. Does she still get the girl. Is it that I have become singularily unable to detect irony. Or is it the result of cultural saturation.

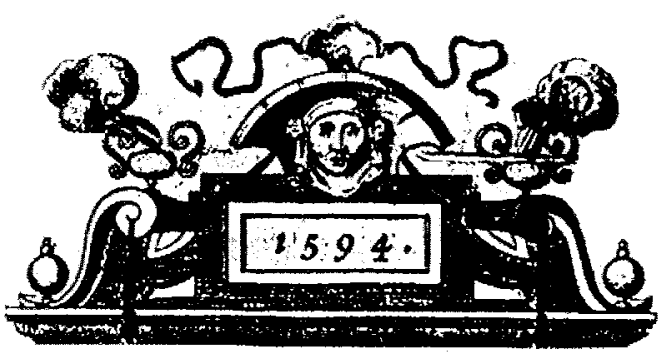


The strain begins to invade our sanctuary showing up in silly argument. She misses an appointment. Plans fall apart. We rearrange the meeting schedule. The warehouse is no longer safe. We have been infiltrated by the enemy who feel threatened by our very existence. We break into factions. Wechangebase, wemeet in public. The agenda evaporates and we talk about everything under the zodiac. We go back in time to the mid ' 70 's as if we can fall through a crack in innocence. To a time when we were bad girls before we became bad women. Our voices raised in event. But then. Eventually Super Nevada wentsupernova. Wefellapartasa body of resistance.

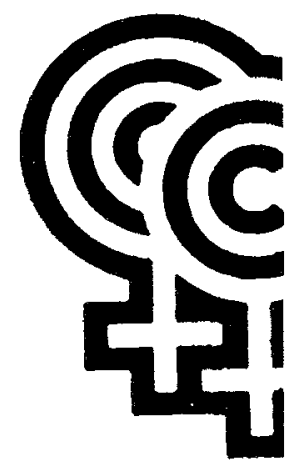

By this time he has plenty of ideas for saving himself. We pour over train schedules. We bring home brochures from the travel agent. We plan his itinerary and chose the date of departure. All he needs now is the money. The date of our separation grows nearer and nearer. Already I am waiting for his return when things begin to go wrong. Every industry is affected by the recession. Every day there are reports of raids at the border. We begin to trust no one. The day fixed for his departure comes and goes. There are sensational accounts in the papers. Perfect traps have been laid and everything has been seized. Thousands lose their businesses overnight. Information is leaking through, underground. The papers report the death toll and then revise it. We are anxious and the money doesn't come. He stands in lineups at the bank in vain. His eventual return becomes an impossible fantasy as itbecomes moreand more apparent that he will never leave. We have no idea how involved we've become in the resistance. The files on us are getting fatter by the minute. We have been photographed at demonstrations by plainclothes police with telephotolenses. They believe in their absolute power. It is terribly appealing and has terrible consequences for the women! Who advocate peace. 


\section{ONLI TWO}

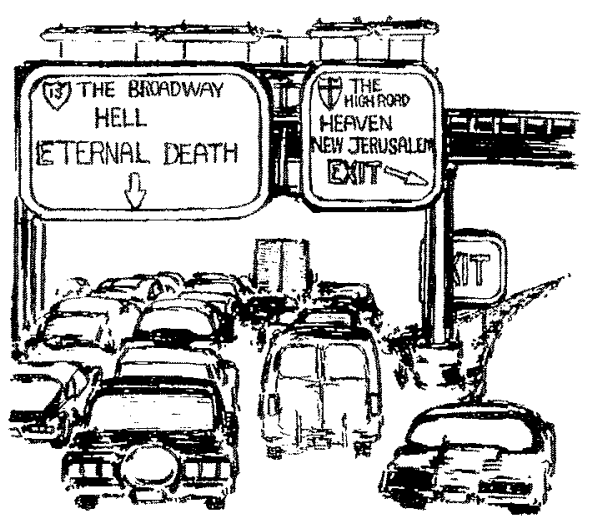

Somehow we manage to transform experience. Much later we will have fond memories. Recalling only love. Small Nevada moments, automatic as light, that engender this fierce loyalty between us women. Never underestimate girl talk. And remember, all history is revisionist.

I sit at the cafe for hours, no one comes. I'm not discouraged. My idea of time is incongruous with the city's. I don't mind working for change that may not come in my life. I get home late. There is a note on the table. It says, I've moved upstairs, love K.
Implication is more dangerous than fact. The Super Nevada Club is under arrest. Charged with estrogen coursing through our bodies. Caught wearing wigs, incognito in the city, unmasked with each other and unable to hide(oursmiles behind ourhands).Knowing civilization is in transition.

You can leam the most basic and natural laws of life itself. They have been discovered and you can know and use them to improve your own life. In this text you will learn:

The actual laws of understanding and how to use them to improve communication will others

The three conditions of existence that comprise life and how these affect your ability to enjoy it

The anatomy of problems and how to resolve them

- The eight basic urges in life and how to use these to live your life the way you want to

The three classes of universes and how these influence you

- And much more.

A modest man never talks of himself. $\odot$ 


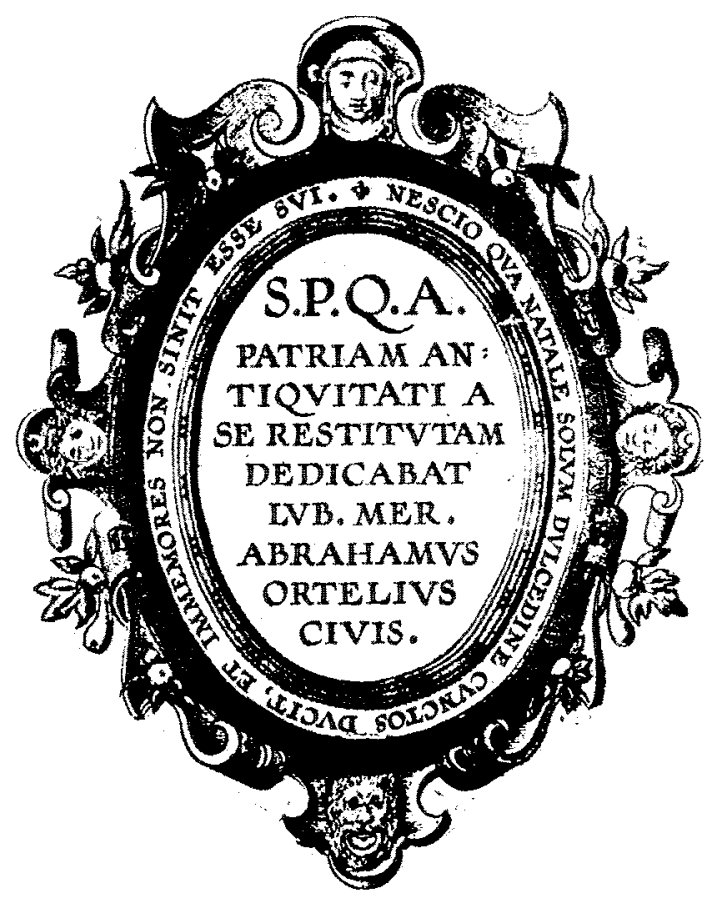

$\begin{array}{lll}\text { Could you show me } & \text { Puede usted } & \text { PWEH-deh oo-STEHD } \\ \text { in the map? } & \begin{array}{l}\text { indicármelo en el } \\ \text { mapa? }\end{array} & \text { loh-de日-KAHR-meh- } \\ & & \text { lohn ehl MAH-pab? }\end{array}$

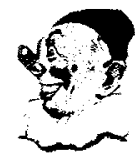

(This Tract and Odhers Free as the Lurd Provides)

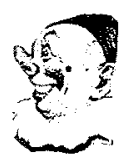

